\title{
Annualized Agricultural Non-Point Source model application for Mississippi Delta Beasley Lake watershed conservation practices assessment
}

\author{
Y. Yuan, M.A. Locke, and R.L. Bingner
}

\begin{abstract}
The Annualized Agricultural Non-Point Source (AnnAGNPS) model has been developed to quantify watershed response to agricultural management practices. The objective of this study was to identify critical areas where conservation practices could be implemented and to predict their impact on Beasley Lake water quality in the Mississippi Delta using AnnAGNPS. Model evaluation was first performed by comparing the observed runoff and sediment from a US Geological Survey gauging station draining 7 ha $(17 \mathrm{ac})$ of Beasley Lake watershed with the AnnAGNPS simulated runoff and sediment. The model demonstrated satisfactory capability in simulating runoff and sediment at an event scale. Without calibration, the Nash-Sutcliffe coefficient of efficiency was 0.81 for runoff and 0.54 for sediment; the relative error was 0.1 for runoff and 0.18 for sediment, and the Willmott index of agreement was 0.94 for runoff and 0.80 for sediment. The quantity of water and sediment produced from each field within the Beasley Lake watershed, quantity of water and sediment reaching Beasley Lake, and the potential impact of various USDA Natural Resources Conservation Service conservation programs on water quality were then simulated. High sedimentproducing areas for nonpoint source pollution control were identified where sediment loads could be reduced by $15 \%$ to $77 \%$ using conservation practices. Simulations predicted that converting all cropland to no-till soybeans (Glycine $\max$ [L.] Merr.) would reduce sediment load by $77 \%$ whereas no-till cotton (Gossypium hirsutum L.) would reduce it $64 \%$. The approach taken in this study could be used elsewhere in applying AnnAGNPS to ungauged watersheds or watersheds with limited field observations for conservation program planning or evaluation.
\end{abstract}

Key words: Annualized Agricultural Non-Point Source (AnnAGNPS) model-Conservation Effects Assessment Project (CEAP)—conservation practice assessment-nonpoint source pollution-runoff and sediment simulation-watershed modeling

To mitigate nonpoint source water quality problems, best management practices (BMPs) and/or conservation programs have been adopted to reduce sediment and pollutant losses from agricultural areas. This includes various conservation tillage (e.g., no-tillage, mulch tillage, and reduced tillage) options (Andraski et al.2003; Daverede et al. 2003; Dabney et al. 2004; Locke et al. 2005), Conservation Reserve Program (CRP) practices such as grass filter strips and riparian buffers (Dillaha et al. 1989; Line 1991; Cooper and Lipe 1992; Robinson et al. 1996; Hussein et al. 2007), and in-field structures such as impoundments that retard flow and allow suspended sediment sufficient time to settle out (Laflen et al. 1978; Lindley et al.1998). Data on how these programs and practices are affecting water quality is needed to help decision makers determine a cost/ benefit ratio of BMP or conservation program implementation.

Monitoring programs are often used to evaluate land management effects on non-point source pollution (Shih et al. 1994). Long-term monitoring better reflects multi-year climatic variability and helps assure that a range of events and conditions are covered (Stone et al. 2000; Borah et al. 2003). Because long-term monitoring is expensive and often limited by personnel and financial resources, short-term monitoring with complimentary simulation modeling may be used as an alternative for $\mathrm{BMP}$ or conservation program evaluation.

Models such as the Annualized Agricultural Non-Point Source (AnnAGNPS) model (Bingner et al. 2003) have been developed to aid in the evaluation of watershed response to agricultural management practices. Through a continuous simulation of runoff, sediment, and pollutant loadings from watersheds, BMPs or conservation programs can be evaluated. Many studies have evaluated AnnAGNPS's capability in predicting runoff and sediment (Yuan et al. 2001; Suttles et al. 2003; Baginska et al. 2003; Shrestha et al. 2006; Licciardello et al. 2007). Yuan et al. (2001) applied AnnAGNPS to the Deep Hollow Lake watershed in the Mississippi Delta and found that the simulated monthly runoff and sediment were well-correlated with observed values $\left(r^{2}=0.9\right.$ for runoff and 0.7 for sediment). Suttles et al. (2003) also concluded that AnnAGNPS-simulated and observed runoff and sediment were well matched (100\% for runoff and 106\% for sediment) at the outlet of the Little River watershed in southcentral Georgia. Baginska et al. (2003) evaluated AnnAGNPS's performance on a small experimental catchment within the Hawkesbury-Nepean drainage basin of the Sydney region. Their results also showed that AnnAGNPS produced satisfactory results when simulating event flows. Shrestha et al. (2006) evaluated the capability of AnnAGNPS in predicting runoff volume and sediment load with two years of field observations from a watershed in the Siwalik Hills of Nepal.They concluded that the model predicted the runoff volume within the range of acceptable accuracy and sediment in the range of moderate accuracy. Licciardello et al. (2007) evaluated the AnnAGNPS model using seven-year monitoring data from an experimental watershed of mainly pasture in Sicily, Italy. Their evaluation results showed that the model was satisfactory in predicting

Yongping Yuan is a research scientist for the National Center for Computational Hydroscience and Engineering at the University of Mississippi, Oxford, Mississippi. Martin A. Locke is the research leader at the Water Quality and Ecology Research Unit, National Sedimentation Laboratory, USDA Agricultural Research Service (ARS), Oxford, Mississippi. Ronald L. Bingner is an agricultural engineer at the Watershed Physical Processes and Water Quality and Ecology Research Unit, National Sedimentation Laboratory, USDA ARS. 
surface runoff at event, monthly, and annual scales after calibration. For sediment, high values of the coefficient of determination and model efficiency were achieved for the 24 suspended sediment load events recorded during the entire period of observation after reducing the roughness coefficients and Manning's roughness coefficients for both rangeland and cropland areas.

Our overall objective was to quantify the effects of land use and management changes within the Mississippi Delta Beasley Lake watershed (BLW) on runoff and sediment losses. Specifically, we wanted to (1) determine sediment loads and sources currently transported within BLW, (2) identify the critical areas causing serious sediment problems, (3) estimate the need for conservation practices and simulate alternative options for implementing conservation programs on cropland, and (4) evaluate the benefits that could be realized if appropriate conservation practices were implemented.

\section{Materials and Methods}

AnnAGNPS Model Description. AnnAGNPS is an advanced simulation model developed by the USDA ARS and Natural Resources Conservation Service (NRCS) to help evaluate watershed response to agricultural management practices (Bingner et al. 2003). It is a continuous simulation, daily time step, pollutant loading model designed to simulate water, sediment, and chemical movement from agricultural watersheds (Bingner et al. 2003). The AnnAGNPS model evolved from the original single event AGNPS model (Young et al. 1989) but includes significantly more advanced features than AGNPS. The spatial variability of soils, land use, and topography within a watershed can be determined by dividing the watershed into many user-specified, homogeneous, drainage-areadetermined cells. From individual cells, runoff can be predicted from precipitation events that include rainfall, snowmelt, and irrigation. (The complete AnnAGNPS model suite, which includes programs, pre- and postprocessors, technical documentation, and user manuals, is available at http://www.ars. usda.gov/Research/docs.htm?docid=5199).

The hydrology components considered within AnnAGNPS include rainfall, interception, runoff, evapotranspiration (ET), infiltration/percolation, subsurface lateral flow and subsurface drainage. The runoff from each cell is calculated using the Soil
Conservation Service curve number (CN) method (USDA Soil Conservation Service 1985). The modified Penman equation (Penman 1948; Jenson et al. 1990) is used to calculate the potential ET, and the actual ET is represented as a fraction of the potential ET. The fraction is a linear function of soil moisture between wilting point and field capacity. For percolation, only the downward drainage of soil water by gravity is calculated (Bingner et al. 2003). Lateral flow is calculated using the Darcy equation, and subsurface drainage is calculated using Hooghoudt's equation (Freeze and Cherry 1979; Smedema and Rycroft 1983; Yuan et al. 2006).

Sheet and rill soil erosion for each runoff event is calculated using the Revised Universal Soil Loss Equation (RUSLE) model (Renard et al. 1997). A delivery ratio, which quantifies the amount of sediment deposited in the field and the amount of sediment delivered to the stream, is calculated using the Hydrogeomorphic Universal Soil Loss Equation (HUSLE) model (Theurer and Clarke 1991). The Bagnold equation (Bagnold 1966) is used within AnnAGNPS to determine the sediment transport capacity of the stream, and a modified Einstein equation is used to determine the sediment transport in the stream system (Bingner and Theurer 2001).

AnnAGNPS simulates runoff and sediment leaving the land surface and being transported through the watershed channel system to the watershed outlet on a daily time step basis. The model routes the physical and chemical constituents from each AnnAGNPS cell into the stream network and finally to the watershed outlet and has the capability to identify the sources of pollutants at their origin and track them as they move through the watershed system.

Required input parameters for application of the model include climate data, watershed physical information, and land management operations. Daily climate information is required to account for temporal variation in weather, and multiple climate files can be used to describe the spatial variability of weather. Output files can be produced to describe runoff and sediment loads on a daily, monthly, or yearly basis. Output information can be specified for any desired watershed source location such as specific cells, reaches, feedlots, or point sources. Additional information describing AnnAGNPS can be found in Bingner et al. (2003).
Beasley Lake Watershed Description and Data Collection. Beasley Lake watershed is located in Sunflower County, Mississippi, and is a part of the Mississippi Delta (figure 1). Characteristics of the BLW are more fully described in Locke et al. (2008), but in general, this 915 ha $(2,260 \mathrm{ac})$ area is very flat, with a $5 \mathrm{~m}(16 \mathrm{ft})$ difference in elevation from the upper watershed boundary to the lake surface. Drainage is largely dependent on man-made ditches and a large riparian area. The watershed is a relatively closed system except during extremely wet periods (usually in spring or fall) when the lake overflows into the Sunflower River. The BLW was included in the Mississippi Delta Management Systems Evaluation Area project (1995 to 2003), and edge of field conservation practices such as stiff grass hedges and grade control pipes were implemented (Locke 2004). These edge-of-field BMPs, in addition to other practices such as reduced tillage, decreased lake sediment by 34\% from 1995 through 2003 (Knight and Welch 2004).

Detailed records of field operations, including crop, planting date, fertilizer and pesticide applications, cultivation events, and harvest dates have been maintained since 1996. A cotton-soybean or cotton-corn (Zea mays L.) rotation was common in the BLW when monitoring began. From 1995 to 2002,660 ha $(1,630 \mathrm{ac})$ were cropped with cotton, corn, and soybeans, with cotton being the dominant crop (70\%). From 2003 to present, the dominant crop $(>50 \%)$ was soybeans, but cotton, corn, and sorghum (Sorghum bicolor L.) were also produced.

Toward the end of the Mississippi DeltaManagement Systems Evaluation Area project, farmers and landowners within the watershed began to implement conservation practices, including reduced-tillage (USDA NRCS Code 329B) cotton and no-tillage (USDA NRCS Code 329A) soybean. From 2003 to 2004,113 ha $(280 \mathrm{ac})$ were removed from row crop production and planted to hardwood trees under CRP. All these conservation practices are widely used today (Snipes et al. 2004) in the Mississippi Delta, but their relative contributions to water quality improvement are uncertain.

The US Geological Survey (USGS) installed a gauging station in 1995 to 1996 to monitor runoff, sediment, nutrient, and pesticide loadings from a 7 ha $(17 \mathrm{ac})$ drainage area entering Beasley Lake (figure 1). 


\section{Figure 1}

Aerial photo of Beasley Lake watershed.

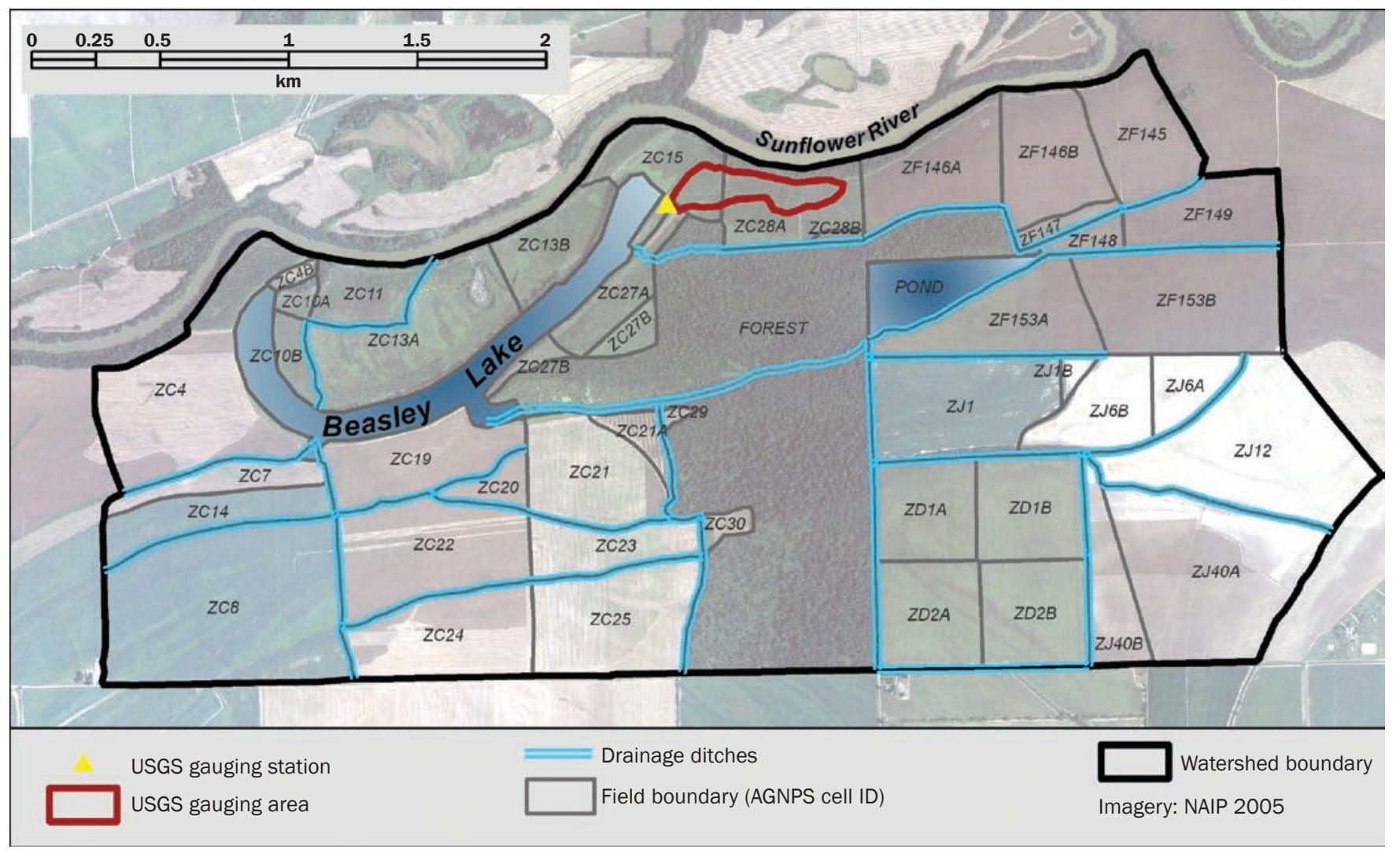

Data from this station were used to evaluate the performance of AnnAGNPS. Runoff was monitored using a critical flow flume, with both discrete and composite samples being taken during rainfall events for sediment analyses. Rainfall was monitored at the flume using a tipping bucket raingauge (Rebich 2004).

AnnAGNPS Input Preparation. For validation studies, accurate information is needed to describe the watershed and develop the input parameters used in watershed simulations. The information necessary for AnnAGNPS simulations can be categorized as physical, management, and climate components. Physical information includes topographic data needed to describe watershed and subarea boundaries (AnnAGNPS cells), and channel reaches (AnnAGNPS reaches) and characteristics. Management information includes various field management operations such as planting, cultivation, fertilization, pesticides, and harvesting, much of which can be obtained from RUSLE (Renard et al. 1997) databases or from actual activities implemented.
AnnAGNPS Cell and Reach Data. The watershed can be divided into subareas of any size and shape (defined as AnnAGNPS cells) based on their drainage areas, average elevation, land slope, slope direction, RUSLE/USLE "LS" factor, time of concentration, and associated soils and management properties. Each AnnAGNPS cell drains into a channel reach where reach elevation, slope, and length are required. More information on input specification can be found from Darden et al. (2007). In many cases, AnnAGNPS cell and reach parameters can be produced with a customized ArcView geographical information system interface using a geographical information system digital elevation model. However, for the BLW, a customized approach was needed because the topography is flat, and drainage depends largely on constructed drainage ditches.

Each field as shown in figure 1 in the BLW was treated as an individual AnnAGNPS cell since the constructed drainage ditches divided the watershed into many fields, and surface runoff from fields was routed to the lake through these drainage ditches. The runoff generated in each AnnAGNPS cell is assumed to be directly delivered to the receiving reach of the AnnAGNPS cell with no surface runoff flowing between cells. A detailed field investigation was performed to identify how runoff from each field was routed to the corresponding drainage ditch. Three-dimensional surveys (positions $\mathrm{x}, \mathrm{y}$; and elevation z) were performed for each field using a global positioning system (TOPCON HiPer+) with an accuracy of $1 \mathrm{~cm}(0.4 \mathrm{in})$ in all directions. Results were used to determine the required AnnAGNPS cell topographic parameters. Sheet flow slope and length, shallow concentrated flow slope and length, and concentrated flow slope and length were determined based on Technical Release 55 (USDA NRCS 1986). Drainage ditch surveys were also performed with the results being used to develop the reach parameters for the AnnAGNPS simulations.

Soils, Land Use, and Field Management. A digital soil survey of the BLW was obtained from the Sunflower County, Mississippi, USDA NRCS office. Geographical information system soil maps were used in conjunction with the field maps to determine the predominant soil assigned to each field (figure 
1). Soil parameters were obtained from the National Soil Information System database and formatted using the AnnAGNPS Input Editor, a graphical user interface designed to aid users in selecting or organizing appropriate input parameters (Darden et al. 2007).

For land-use and field management information, three evaluation schemes were considered during input file development: (1) model performance evaluation, (2) model simulation to represent the current condition of the watershed to identify critical areas where serious soil erosion was occurring, and (3) conservation practices evaluation. Since monitored runoff and sediment data from the USGS gauging station were available from 1996 to 2000 (Rebich 2004), actual records of field operation and crop management from 1996 to 2000 were used to develop land-use and management schedules for model performance evaluation. To represent the current condition of the watershed, actual field operation and crop management information was extended to 2003 to develop land-use and management schedules for AnnAGNPS simulation because of the availability of the data. Actual field operation and crop management information was described with as much detail as possible, based on RUSLE guidelines and databases (Renard et al. 1997), for operations causing soil disturbance or land cover changes. The actual date of activities is very important for model performance evaluation and current condition evaluation. To evaluate the effects of conservation practices, USDA NRCS conservation programs and their guidelines were reviewed and used to develop various land-use and management practices (USDA NRCS 2007).

The Soil Conservation Service CN is a key factor in obtaining accurate prediction of runoff and sediment yields. Curve numbers vary between wilting point (CN1) and field capacity (CN3). Our values, corresponding to the water content halfway between wilting point and field capacity (Bingner and Theurer 2001), were selected based on the National Engineering Handbook, Section 4 (USDA Soil Conservation Service 1985).

Climate Information. Daily maximum, minimum and dew point temperature, precipitation, sky cover, and wind speed are needed to account for temporal variation in weather. This data can be historically measured, estimated using the climate generator program-GEM, or supplied to AnnAGNPS using a combination of the two methods. For this study, the climate file has to be developed to serve all three simulation purposes as discussed above. Therefore, several steps were involved in building climate files to evaluate the model performance, current condition of the watershed and conservation practices already implemented or to be implemented in the BLW. Recognizing the need for longterm evaluation of conservation practices, a 35-year weather file representing 1971 to 2005 was first produced using the GEM program (USDA ARS 2007; Johnson et al. 2000) for the long-term conservation practice assessment. To develop a climate file to simulate the current condition of the watershed, the Mississippi Delta weather information monitored by the Delta Agricultural Weather Center at the Delta Research and Extension Center near Stoneville, Mississippi, was collected and analyzed. The closest weather station at Stoneville, $25 \mathrm{~km}$ (16 mi) away from the BLW, has monitored maximum and minimum temperature, precipitation, and wind speed since January 1, 1996. Beasley Lake weather station has monitored the same information since January of 2000 Since detailed field operation and management were recorded from 1996, the second climate file was developed by modifying the 35-year synthetic weather file using the climate information recorded at the Stoneville weather station and the Beasley Lake.The climate information recorded at the Stoneville weather station was used to replace generated maximum and minimum temperature, precipitation and wind speed from 1996 to 1999. From 2000 to 2003, recorded weather information at Beasley Lake were used to replace generated maximum and minimum temperature, precipitation and wind speed. The rest of the weather parameters have a minor impact on the results, so no additional measured weather parameters were used. Finally, the third climate file was developed based on the second climate file by using measured precipitation from 1996 to 2000 at the USGS gauging station for model performance evaluation.

Model Evaluation. The USGS gauging station was frequently flooded because of the flat topography within the drainage area, and accurate measurements of runoff and sediment were not obtained for all rainfall events. Therefore, the USGS stage discharge record was carefully examined for each event and for those flooded events that were questionable (e.g., when the stage reading stays unchanged at the peak) the data were excluded from the evaluation study.

The observed runoff and sediment from the gauging station were compared with AnnAGNPS simulated runoff and sediment for this area from 1996 to 2000. The NashSutcliffe coefficient of efficiency (NSE) (Nash and Sutcliffe 1970), the relative error (RE), the Willmott index of agreement (Willmott 1984) and visual data analysis were used to evaluate the model's performance. The NSE ranges from $-\infty$ to 1 , with one indicating the model is perfect (Nash and Sutcliffe 1970). The NSE is computed as shown in the following equation:

$N S E=1-\left[\frac{\sum_{i=1}^{n}\left(Y_{i}^{\text {obs }}-Y_{i}^{\text {sim }}\right)^{2}}{\sum_{i=1}^{n}\left(Y_{i}^{\text {obs }}-Y^{\text {mean }}\right)^{2}}\right]$,

where $Y_{i}^{\text {obs }}$ is the ith observation for the constituent being evaluated, $Y_{i}^{\text {sim }}$ is the ith simulated value for the constituent being evaluated, $Y^{\text {mean }}$ is the mean of observed data for the constituent being evaluated, and $n$ is the total number of observations. The RE is the ratio between the total difference and the total observed value, and it ranges from -1 to $\infty$. Zero indicates that there is no difference between model simulation and field observation. The smaller the absolute value of a $\mathrm{RE}$, the better performance of the model is. The index of agreement $(d)$ was developed by Willmott (1984) as a standardized measure of the degree of model prediction error and varies between 0 and 1.A computed value of 1 indicates a perfect agreement between the measured and predicted values, and 0 indicates no agreement at all (Willmott 1984). The index of agreement can be calculated as shown in the following equation:

$$
d=1-\left[\frac{\sum_{i=1}^{n}\left(Y_{i}^{\text {obs }}-Y_{i}^{\text {sim }}\right)^{2}}{\sum_{i=1}^{n}\left(\left|Y_{i}^{\text {sim }}-Y^{\text {mean }}\right|+\left|Y_{i}^{\text {obs }}-Y^{\text {mean }}\right|\right)^{2}}\right] .
$$

The visual analysis was straightforward through the inspection of the graphs.

Model Simulations of Current Conditions and Alternative Management Scenarios. After AnnAGNPS simulations were evaluated based on the USGS gauging station, the AnnAGNPS simulation for the entire BLW for 1996 to 2003 was performed to estimate 
current sediment transport in the watershed with actual rainfall, land-use, and field management. This provided an identification of critical areas that could cause serious problems, since AnnAGNPS has the capability to identify pollutant sources at their origin and track them as they move through the watershed. Results from this simulation were used as a baseline or a reference for additional simulations of various agricultural management practices including different tillage operations and/or land uses.

Using the AnnAGNPS simulation for 1996 to 2003 as a baseline, all AnnAGNPS cells were sorted, based on their highest erosion rate, and grouped into several levels. Then various agricultural management practices including different tillage operations and/or land uses were applied and evaluated. The effect of conservation-tillage was evaluated by converting the watershed to different percentages of no-tillage crop production, and the effect of land use was evaluated by converting various areas of cropland to grass or trees or a combination of the two (CRP). No-tillage/CRP was applied by converting the most erodible areas to no-tillage/CRP based on the spatial distribution of the results from current condition simulation of the watershed. Percentage of no-tillage or grassland conversion was arbitrarily defined with an emphasis on the importance of targeting the most critical areas that could cause serious sediment problems. Application of no-tillage or grassland to the watershed was on a cell basis because cells are the basic computational areas of AnnAGNPS. To appropriately evaluate the effects of the various management alternatives, 35-year simulations were performed using the 35-year synthetic weather file.

We focused on those scenarios that had a chance of being implemented based on NRCS conservation programs (USDA Natural Resources Conservation Service 2007) or for which financial incentive programs existed or could be developed. Some scenarios could not be realistically implemented (e.g., converting to all no-till or converting all cropland to fall tillage). Evaluating these less realistic scenarios provided results that served as benchmark information or helped in understanding model performance. The fall tillage simulation was thought to represent the worst case scenario for the existing crop land use within the watershed, while the simulation with all

\section{Figure 2 Comparison of observed and simulated runoff by events from the US Geological Survey gauging station.}

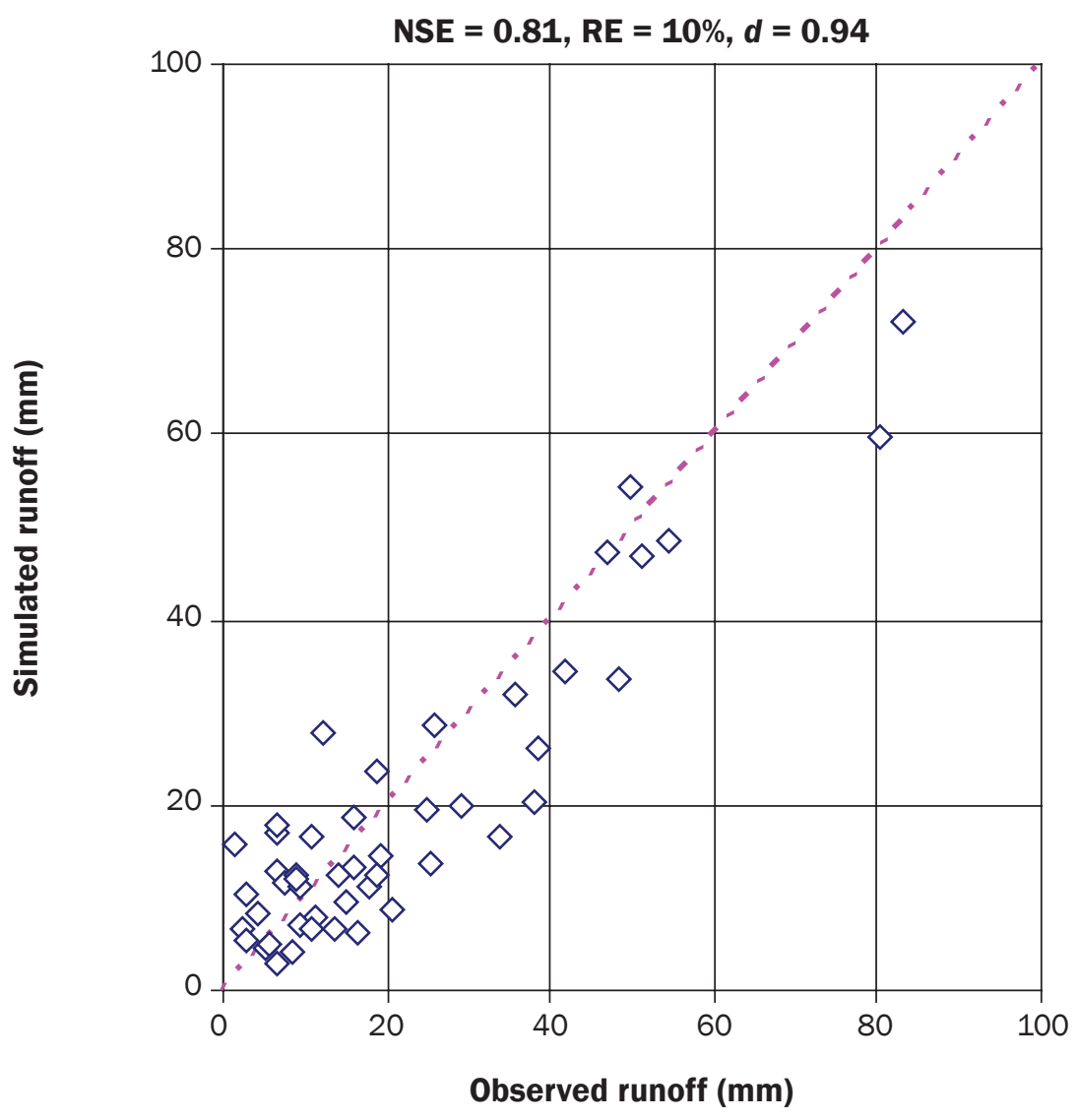

no-tillage represented what was thought to be the best case scenario possible with the existing crop land use in the watershed.

\section{Results and Discussion}

AnnAGNPS simulated runoff and sediment, and the observed runoff and sediment from precipitation events which were available for model evaluation at the USGS gauging station are displayed in figures 2 and 3. Calculated NSE, RE, and index of agreement are also shown in figures 2 and 3 . Results of runoff, soil erosion, sediment yield and sediment load from each field within BLW for the current condition simulation are given in table 1 . Results for alternative scenario simulations are given in table 2 . Soil erosion refers to the amount of soil detached from the landscape; sediment yield refers to the amount of sediment that moves through the landscape and reaches the channel; and sediment load refers to the amount of sediment that moves through stream channels and reaches the watershed outlet (lake).
Model Evaluation. Comparisons between the simulated and observed runoff from individual events at the USGS gauging station produced a NSE of $0.81, \mathrm{RE}$ of 0.1 , and index of agreement of 0.94 (figure 2). Studies performed by Licciardello et al. (2007) in a Mediterranean watershed produced a NSE of 0.76 and RE of -0.4 for runoff comparison without calibration; after calibration, the NSE was 0.84 and RE was zero, and the NSE was 0.83 and RE was 0.32 during validation period. A NSE of 0.82 was achieved by Baginska et al. (2003) on the Currency Creek experimental catchment of the Sydney Region after calibration. Moriasi et al. (2007) thoroughly reviewed literature on model application and recommended model evaluation methods, and they concluded that model simulation can be judged as satisfactory if NSE is greater than 0.50 and very good if NSE is greater than 0.75 for runoff.

The overall model performance was good as values of NSE, RE, and index of agreement $d$ shown in figure 2. Generally, the 


\section{Figure 3}

Comparison of observed and simulated sediment by events from the US Geological Survey gauging station.

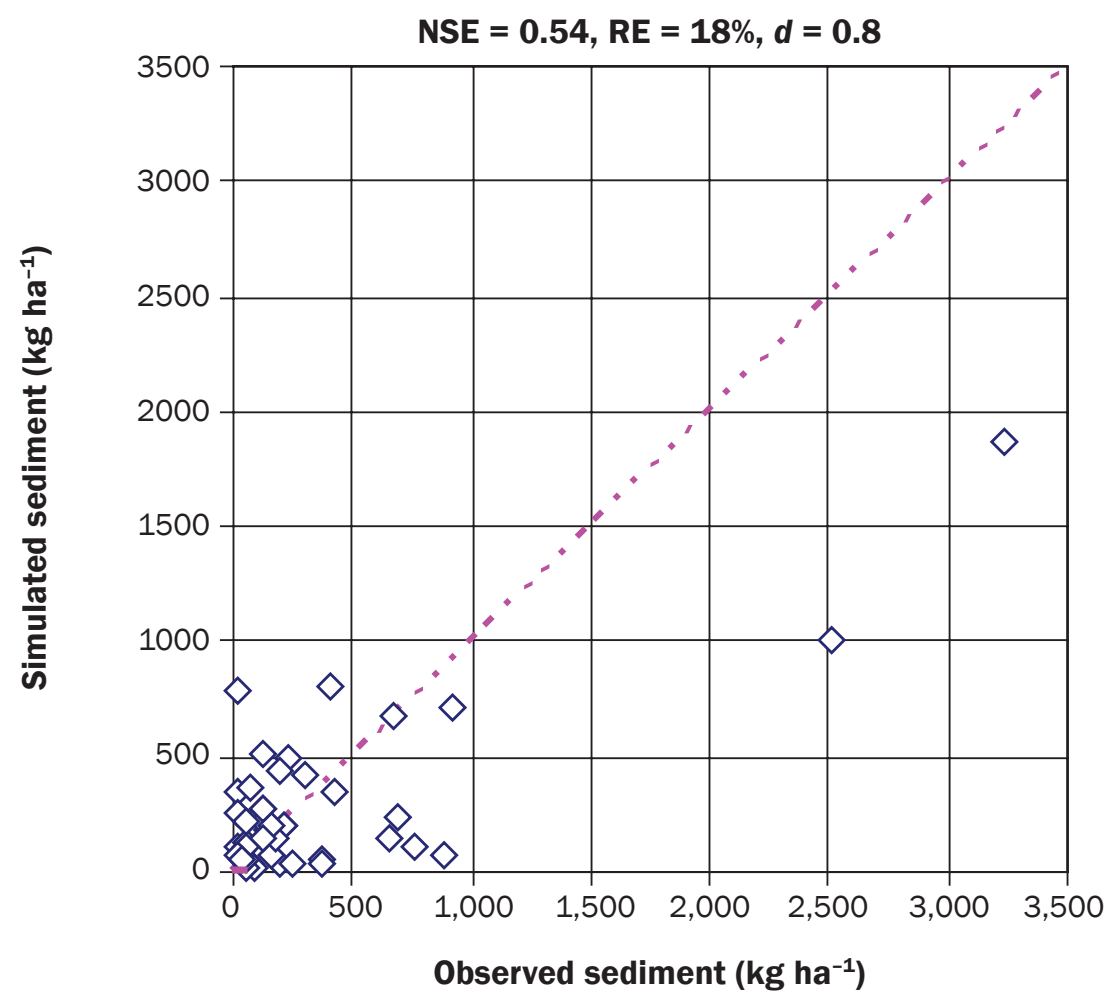

runoff events were slightly under-predicted by AnnAGNPS, although a few rainfall events were over-predicted (figure 2). The AnnAGNPS simulations of the Deep Hollow Lake watershed, approximately $20 \mathrm{~km}(12.5$ mi) from BLW, similarly under-predicted runoff, especially for large rainfall events (over $80 \mathrm{~mm}$ ) (Yuan et al. 2001). Other studies also showed that AnnAGNPS had the tendency to under-predict larger events (Baginska et al. 2003; Licciardello et al. 2007). There is concern that the Soil Conservation Service $\mathrm{CN}$ procedure may not reproduce measured flow from individual storm rainfall because of unique storm characteristics, tillage, and plant growth interactions with previous moisture (Smith 1978; Hawkins 1978, 1979; Hjelmfelt et al. 1981).

For sediment, comparisons of simulated and observed results from individual events produced a NSE of 0.54 , RE of 0.18 , and index of agreement of 0.80 (figure 3 ). Studies performed by Licciardello et al. (2007) had a NSE of 0.51 and RE of 0.53 without calibration. A RE value of 0.26 was achieved after calibration. A RE of 0.59 was achieved by Shrestha et al. (2006) on a watershed in the Siwalik Hills of Nepal. Figure 3 shows some under-predictions and some overpredictions on event scale, and the two largest events were under-predicted possibly due to the under-prediction of runoff (figure 2). The use of RUSLE technology in AnnAGNPS is intended to determine the long-term annual average effects of management practices, so comparisons of individual events for sediment may not agree very well. Yuan et al. (2001) showed that comparisons of sediment at annual or monthly scale achieved better agreement in the Deep Hollow watershed (Yuan et al. 2001), and AnnAGNPS adequately predicted average monthly and annual sediment load. Although the simulation of sediment did not perform as well as runoff, the NSE of 0.54, RE of 0.18 , and index of agreement $d$ of 0.80 all indicated a satisfactory performance of the model in simulating sediment (Moriasi et al. 2007).

Based on the satisfactory performance of the model in simulating runoff and sediment, no further model calibration was performed. This analysis reflects the capability of AnnAGNPS to estimate runoff and sediment that would be typical for ungauged watersheds. AnnAGNPS has been devel- oped to include processes that utilize input parameters-e.g., climate, soil information, and crop management operations-from databases developed by NRCS for any location in the United States. This minimizes the user effort that would otherwise be necessary to acquire the information to calibrate or to apply AnnAGNPS for ungauged watersheds.

Watershed Simulation of Current Conditions. The simulation of current conditions with AnnAGNPS from 1996 to 2003 produced an annual average runoff of 625.6 $\mathrm{mm}$ (24.6 in) and annual average soil erosion of $3.29 \mathrm{Mg} \mathrm{ha}^{-1}\left(1.5 \mathrm{t} \mathrm{ac}^{-1}\right)$ over the entire watershed (table 1). Fields ZC24, ZC23, ZC13B, and ZC15 were found to be the most erodible fields and produced annual average soil erosions greater than $8 \mathrm{Mg} \mathrm{ha}^{-1}$ (3.6 tn ac ${ }^{-1}$ ) (table 1). Field management records showed that those fields were mainly planted in cotton from 1996 to 2003. To achieve the maximum benefit of BMPs, those fields (approximately 7\% of BLW area) were the first to be targeted for BMPs. Results in table 1 also showed that fields ZC13A, ZC11, ZC10, ZC7, ZC25, and $Z C 24$ produced annual average soil erosion less than $8 \mathrm{Mg} \mathrm{ha}^{-1}$ but greater than $7 \mathrm{Mg} \mathrm{ha}^{-1}$ (3.1 tn $\mathrm{ac}^{-1}$ ) (table 1). Thus, those fields (about $10 \%$ of BLW area) were the second tier to be targeted for BMPs. About $16 \%$ of the watershed produced an annual average soil erosion in the range of 4 to $7 \mathrm{Mg} \mathrm{ha}^{-1}$ (1.8 to $3.1 \mathrm{tn} \mathrm{ac}^{-1}$ ) (table 1 ). Altogether, $33 \%$ of the watershed area produced an annual average soil erosion greater than $4 \mathrm{Mg} \mathrm{ha}^{-1}\left(1.8 \mathrm{tn} \mathrm{ac} \mathrm{ac}^{-1}\right)$. On the other hand, forested land produced the least soil erosion, followed by pasture land. In general, cropland consisting of soybean for the majority of the time produced less soil erosion than those fields with cotton. From the field management records, there were fewer cultivation events for soybean than for cotton, and reduced-tillage was implemented in most of the soybean fields after year of 2000 .

Although no observed data were available for comparisons of this simulation, this analysis illustrates the capability of AnnAGNPS applications for ungauged watersheds. The complexity and expensive nature of laboratory and field observations necessitate the development and use of water quality models for watershed evaluation. The significance of a water quality simulation model is that it compliments short-term or limited monitor- 
ing and helps interpolate or extrapolate the limited monitoring results. It is not possible to monitor runoff and sediment from each field in the watershed because of limited resources. Using the AnnAGNPS model after evaluation, the relative impact of current management practices on soil erosion were assessed (table 1).

Evaluation of Alternative Agricultural Management Scenarios. The main focus of the USDA Conservation Effectiveness Assessment Program (CEAP) effort is to produce an assessment of environmental benefits derived from implementing USDA conservation programs. The outcome of the CEAP project will provide the agricultural community, the public, and others involved with environmental policy issues an accounting of the benefits obtained from these conservation program costs (Mausbach and Dedrick 2004). Watershed assessment studies performed by the USDA ARS are a key element of CEAP. Evaluating and improving performance of national assessment models and producing user-friendly computer models that can be used to evaluate the water quality impacts of varied agricultural land use practices across a wide range of agroecosystems are some of the important CEAP goals. Since much of the conservation program assessment would be performed by models, given the difficulties of obtaining long-term monitoring data, application of AnnAGNPS model for BLW conservation practices assessment provides an excellent illustration. The BLW was selected as one of the 14 USDA ARS CEAP benchmark watersheds because it is unique in that it represents a large portion of the Delta agricultural landscape.

A targeted application of 7\% new no-till soybean (scenario B) on the most erodible cropland achieved a $15 \%$ reduction in sediment load to the lake (table 2). As expected, an increase in no-till application achieved a higher sediment reduction. An application of $17 \%$ of new no-tillage (scenario C) on the most erodible cropland achieved a $33 \%$ reduction, and an application of $33 \%$ of new no-tillage (scenario D) on the most erodible cropland achieved a 54\% reduction (table 2). However, the increase in sediment reduction was not commensurate with the increase in no-tillage application. The first 7\% new no-tillage application to the watershed achieved a $15 \%$ reduction, an additional $10 \%$ increase of new no-tillage by changing from scenario $\mathrm{B}$ to scenario
Table 1

AnnAGNPS simulation of current condition of the watershed (average annual results from 1996 to 2003).

\begin{tabular}{|c|c|c|c|c|c|}
\hline Cell ID & $\begin{array}{l}\text { Area } \\
\text { (ha) }\end{array}$ & $\begin{array}{l}\text { Runoff } \\
(\mathrm{mm})\end{array}$ & $\begin{array}{l}\text { Landscape } \\
\text { soil erosion } \\
\left(\mathrm{Mg} \mathrm{ha}^{-1} \mathrm{y}^{-1}\right)\end{array}$ & $\begin{array}{l}\text { Sediment } \\
\text { yield } \\
\left(\mathrm{Mg} \mathrm{ha}^{-1} \mathrm{y}^{-1}\right)\end{array}$ & $\begin{array}{l}\text { Sediment } \\
\text { load } \\
\left(\text { Mg ha }^{-1} y^{-1}\right)\end{array}$ \\
\hline ZC15 & 12.12 & 462.8 & 8.326 & 5.278 & 5.266 \\
\hline ZC24 & 22.84 & 459.8 & 8.324 & 4.982 & 4.948 \\
\hline ZC23 & 14.57 & 459.8 & 8.324 & 5.368 & 5.193 \\
\hline ZC13B & 10.75 & 459.4 & 8.324 & 5.244 & 5.233 \\
\hline ZC13A & 24.74 & 465.7 & 7.386 & 4.691 & 4.677 \\
\hline ZC10 & 5.27 & 763.8 & 7.306 & 4.487 & 4.477 \\
\hline ZC11 & 8.03 & 763.8 & 7.306 & 4.813 & 4.752 \\
\hline ZC7 & 9.11 & 463.3 & 7.237 & 5.004 & 4.923 \\
\hline ZC25 & 23.73 & 631.8 & 7.182 & 4.453 & 4.343 \\
\hline ZC14 & 12.68 & 459.7 & 7.171 & 4.947 & 4.838 \\
\hline ZC4B & 0.77 & 463 & 6.404 & 3.604 & 3.539 \\
\hline ZC28A & 13.68 & 463.1 & 5.764 & 4.257 & 3.86 \\
\hline ZC27A & 8.35 & 463.2 & 5.764 & 3.725 & 3.552 \\
\hline ZC22 & 26.82 & 717.9 & 5.352 & 3.187 & 3.172 \\
\hline ZC8 & 54.23 & 718 & 5.257 & 3.196 & 3.176 \\
\hline ZC4 & 33.52 & 764.7 & 4.778 & 3.035 & 2.999 \\
\hline ZC28B & 0.64 & 765.7 & 3.816 & 2.555 & 2.412 \\
\hline ZC27B & 4.3 & 765.7 & 3.816 & 2.527 & 2.446 \\
\hline ZJ1 & 35.08 & 455.4 & 3.235 & 1.358 & 1.347 \\
\hline ZC19 & 17.2 & 463.2 & 3.202 & 1.396 & 1.389 \\
\hline ZJ12 & 35.08 & 463.2 & 3.146 & 1.331 & 1.243 \\
\hline ZJ6 & 21.8 & 463.2 & 3.146 & 1.468 & 1.42 \\
\hline ZD1A & 15.81 & 698.1 & 2.964 & 1.501 & 1.485 \\
\hline ZF148 & 3.54 & 720.5 & 2.929 & 2.086 & 2.012 \\
\hline ZF146A & 16.69 & 763.1 & 2.395 & 1.535 & 1.514 \\
\hline ZC20 & 5.26 & 717.8 & 2.389 & 1.248 & 1.225 \\
\hline ZC21 & 22.82 & 713.2 & 2.389 & 1.251 & 1.211 \\
\hline ZF149 & 15.31 & 357.4 & 2.381 & 1.402 & 1.313 \\
\hline ZF153A & 21.17 & 463.7 & 2.38 & 1.038 & 1.029 \\
\hline ZF153B & 31.2 & 463.7 & 2.38 & 1.021 & 0.989 \\
\hline ZJ40A & 41.06 & 845 & 2.343 & 1.079 & 1.039 \\
\hline ZJ40B & 12.38 & 845 & 2.343 & 1.299 & 1.259 \\
\hline ZD2A & 16.37 & 727 & 2.231 & 1.087 & 0.998 \\
\hline ZD2B & 15.55 & 847.6 & 2.227 & 1.147 & 1.106 \\
\hline ZF145 & 16.73 & 763.1 & 2.076 & 1.247 & 1.23 \\
\hline ZF146B & 18.14 & 763.1 & 2.049 & 1.21 & 1.194 \\
\hline ZD1B & 17.12 & 845.9 & 1.565 & 0.807 & 0.8 \\
\hline ZF147 & 3.13 & 720.3 & 1.331 & 0.819 & 0.808 \\
\hline ZC29 & 0.55 & 388.7 & 0.108 & 0.073 & 0.07 \\
\hline ZC30 & 1.83 & 628.1 & 0.093 & 0.063 & 0.06 \\
\hline Forest1 & 115.48 & 591.1 & 0.05 & 0.021 & 0.021 \\
\hline Forest2 & 74.81 & 746.9 & 0.045 & 0.019 & 0.019 \\
\hline Average & & 625.6 & 3.290 & 1.914 & 1.875 \\
\hline
\end{tabular}


Table 2

Summary of simulation results for alternative scenarios.

\begin{tabular}{|c|c|c|c|c|c|c|}
\hline Scenario ID & Description & $\begin{array}{l}\text { Runoff } \\
\text { volume } \\
\text { (mm) }\end{array}$ & $\begin{array}{l}\text { Total } \\
\text { landscape } \\
\text { erosion } \\
\left(\mathrm{t} \mathrm{ha-1} \mathrm{y}^{-1}\right)\end{array}$ & $\begin{array}{l}\text { Total } \\
\text { sediment } \\
\text { yield } \\
\left(\mathbf{t} \text { ha }^{-1} \mathbf{y}^{-1}\right)\end{array}$ & $\begin{array}{l}\text { Sediment } \\
\text { load } \\
\text { at outlet } \\
\left(\mathbf{t} \mathbf{h a}^{-1} \mathbf{y}^{-1}\right)\end{array}$ & $\begin{array}{l}\text { Percent of } \\
\text { existing } \\
\text { condition } \\
\text { loading }\end{array}$ \\
\hline B & $\begin{array}{l}7 \% \text { of the watershed representing the highest } \\
\text { eroding cropland areas ( } 60.3 \mathrm{ha} \text { ) converted to } \\
\text { no-till soybean }\end{array}$ & 578.2 & 2.388 & 1.365 & 1.329 & $85 \%$ \\
\hline D & $\begin{array}{l}33 \% \text { of the watershed representing the highest } \\
\text { eroding cropland areas ( } 281.2 \text { ha) converted to } \\
\text { no-till soybean }\end{array}$ & 569.5 & 1.394 & 0.735 & 0.714 & $46 \%$ \\
\hline $\mathrm{E}$ & All cropland no-tilled soybean & 557.5 & 0.632 & 0.365 & 0.357 & $23 \%$ \\
\hline J & All cropland no-tilled cotton & 557.6 & 1.004 & 0.582 & 0.566 & $36 \%$ \\
\hline K & $\begin{array}{l}7 \% \text { of the watershed representing the highest } \\
\text { eroding cropland areas ( } 60.3 \text { ha) converted } \\
\text { to grassland }\end{array}$ & 568.8 & 2.287 & 1.303 & 1.267 & $81 \%$ \\
\hline L & $\begin{array}{l}17 \% \text { of the watershed representing the highest } \\
\text { eroding cropland areas ( } 143.8 \mathrm{ha} \text { ) converted } \\
\text { to grassland }\end{array}$ & 553.0 & 1.699 & 0.924 & 0.896 & $58 \%$ \\
\hline M & $\begin{array}{l}33 \% \text { of the watershed representing the highest } \\
\text { eroding cropland areas ( } 281.2 \text { ha) converted } \\
\text { to grassland }\end{array}$ & 544.7 & 1.020 & 0.499 & 0.482 & $31 \%$ \\
\hline $\mathrm{N}$ & All cropland converted to grassland & 502.7 & 0.019 & 0.009 & 0.009 & $1 \%$ \\
\hline
\end{tabular}

Notes: The annual average rainfall is $1,352 \mathrm{~mm}$. Percent of existing condition loading in last column is the ratio of sediment load from each alternative scenario to the existing condition.

C resulted in an increase of $18 \%$ sediment reduction, whereas another additional increase of $16 \%$ of new no-tillage from scenario $\mathrm{C}$ to scenario $\mathrm{D}$ resulted in an increase of $21 \%$ sediment reduction (table $2)$. Thus, it is important to target critical areas that have serious erosion first so cost/ benefit ratios can be optimized and nonpoint source pollution control can be achieved in the most efficient way. In reality, however, implementing no-tillage on all of the most erodible areas is probably not politically or programmatically feasible because this land treatment program relies on voluntary incentives.

A reduction of $77 \%$ in sediment load from scenario A (current condition) would be achieved if all crop fields were converted to no-tillage soybean (scenario E). If the reduced tillage system instead of the no-tillage system was applied to the same fields, a $57 \%$ reduction would be achieved in sediment load (scenario F). Similarly, a 55\% reduction would be achieved if the conventional tillage systems were applied to these soybean fields (scenario G). However, when converting all crop fields to conventional tillage cotton, the sediment load would be increased by $20 \%$ (scenario $\mathrm{H}$ ). This represents the worst case situation that could happen for the existing land use within the watershed. A better scenario over conventional tillage cotton would be reduced tillage cotton or no-tillage cotton. The reduced tillage cotton would increase sediment load by $14 \%$ (scenario I); whereas no-tillage cotton would decrease sediment load by $64 \%$ (scenario J). For the same tillage system, planting soybean resulted in less sediment load to the lake than planting cotton (table 2) because soybean produces more residue, providing more protection of the soil. It should be noted that the differences in sediment load between reduced tillage and conventional tillage were small because the differences between those two tillage systems were not substantial in this area.

While converting the most erodible cropland to no-till soybean reduced sediment load to the lake, converting the most erodible cropland to grassland also reduced sediment load to the lake. A more efficient scenario was $\mathrm{K}$, which converted $7 \%$ of the highest erodible areas to grassland and achieved a $19 \%$ reduction in loading (table 2). As expected, an increase in grassland application achieved a higher sediment reduction; an application of $17 \%$ of new grassland (scenario L) on the highest erodible areas achieved a $42 \%$ reduction in sediment load, and an application of $33 \%$ of new grassland (scenario M) on the highest erodible areas achieved a $69 \%$ reduction in sediment load (table 2). Similarly, the increase in sediment reduction was not on the same pace as the increase in grassland application. The first $7 \%$ new grassland application to the watershed achieved a 19\% reduction, an additional $10 \%$ increase of new grassland from scenario $\mathrm{K}$ to scenario $\mathrm{L}$ resulted in an increase of $23 \%$ reduction, whereas an additional 16\% increase of new grassland from scenario L to scenario $M$ resulted in an increase of $27 \%$ reduction (table 2).

Increases in both no-tillage and grassland areas to the watershed would reduce land- 
scape erosion, which in turn would reduce sediment yield and load (table 2). However, new applications of grassland areas are more efficient than new applications of no-tillage areas in sediment reduction. The 17\% new grassland area (scenario L) achieved a $42 \%$ reduction, whereas $17 \%$ of new no-tillage area (scenario C) achieved a 33\% reduction (table 2). The model as run for this project did not have a riparian buffer or filter strip component. The effectiveness of grass buffers captured in the model represented only the effect of land cover change on erosion and not the benefits that would accrue from any trapping efficiency when edge-of-field practices are positioned adjacent to a water body. Thus the model may have underestimated the effects of these practices.

Although models are simplifications of the real world and uncertainty is an inevitable part of model simulation, through AnnAGNPS simulations of the alternative scenarios, relative impact of conservation practices can be compared which could be used as guidelines for future conservation practice planning.

\section{Summary and Conclusions}

The BLW located in Sunflower County, Mississippi, was selected as one of the 14 USDA ARS CEAP benchmark watersheds because it is unique in that it is characteristic of a large portion of the Delta cottonsoybean production landscape. A study was conducted to evaluate the effects of land use and management changes on sediment losses from agricultural fields. This was accomplished by intensive field data collection and analysis as well as evaluations with the AnnAGNPS model.

Various data collected to describe the watershed included: climate, detailed topographic and soil survey of the watershed, land use and field management practices implemented in the watershed, and runoff and sediment monitored from a 7-ha (17-ac) subarea of the watershed. This information was used to develop AnnAGNPS simulations as well as to evaluate the model's performance.

Comparisons of AnnAGNPS simulated runoff and sediment with observed runoff and sediment from the USGS gauging station on an event basis produced a NSE of $0.81, \mathrm{RE}$ of 0.1 and index of agreement of 0.94 for runoff; a NSE of 0.54 , RE of 0.18 and index of agreement of 0.80 for sediment.
Comparisons of those evaluation criteria values with values obtained from other model applications indicated a satisfactory performance of AnnAGNPS in predicting runoff and sediment. Thus, AnnAGNPS was further applied to simulate the quantity of water and sediment produced from each field within the entire BLW. Results from this simulation allowed an assessment of the relative impact of implemented practices in the watershed on soil erosion that enabled the identification of critical areas that could cause serious problems.

Using results from the AnnAGNPS simulation of current conditions (1996 to 2003) as a baseline, various agricultural management practices including different tillage operations and/or land uses were applied and evaluated. The effect of conservationtillage was evaluated by converting the watershed to different percentages of no-tillage crop production, and the effect of land use was evaluated by converting various areas of cropland to different levels of grass or trees or a combination of the two (CRP). Simulations of various conservation practices illustrated the capability of AnnAGNPS to be used in assessing the impact of conservation practices. The model demonstrated that applications of no-tillage or grassland to targeted areas in the watershed could reduce sediment loads to a range of $15 \%$ to $77 \%$ of the existing condition. Converting all the cropland to no-tillage soybean would reduce sediment load by $77 \%$; whereas converting all the cropland to no-tillage cotton would reduce sediment load by $64 \%$. The approach used in the present study may guide others in applying simulation models to assess effects of conservation practices for ungauged watersheds or watersheds with limited monitoring information.

\section{References}

Andraski, T.W., L.G. Bundy, and K.C. Kilian. 2003. Manure history and long-term tillage effects on soil properties and phosphorus losses in runoff. Journal of Environmental Quality 32(5):1782-1789.

Baginska, B., W. Milne-Home, and P.S. Cornish. 2003. Modeling nutrient transport in Currency Creek, NSW with AnnAGNPS and PEST. Environmental Modeling \& Software 18(8):801-808.

Bagnold, R.A. 1966. An approach to the sediment transport problem from general physics. USGS Professional Paper 422-J. Reston, VA: US Geological Survey.

Bingner, R.L., and F.D. Theurer. 2001. AnnAGNPS: Estimating sediment yield by particle size for sheet \& rill erosion. In Proceedings of the Seventh Interagency Sedimentation Conference, Reno, NV, March 25-29, 2001.Vol. 1 (I):1-7.
Bingner, R.L., F.D. Theurer, and Y. Yuan. 2003. AnnAGNPS Technical Processes. http://www.ars.usda. gov $/$ Research $/$ docs.htm?docid $=5199$.

Borah, D.K., M. Bera, and S. Shaw. 2003. Water, sediment, nutrient, and pesticide measurements in an agricultural watershed in Illinois during storm events. Transactions of the ASAE 46(3):657-674

Cooper, C.M., and W.M. Lipe. 1992. Water quality and agriculture: Mississippi experience. Journal of Soil and Water Conservation 4(3):220-223.

Dabney, M.S., G.V.Wilson, K.C. Mcgregor, and G.R. Foster. 2004. History, residue, and tillage effects on erosion of loessial soil. Transactions of the ASAE 47(3):767-775.

Darden, R., V. Justice, R.L. Bingner, and F.D. Theurer. 2007. AGNPS Input Data Preparation Model User's Guide Version 4. www.wsi.nrcs.usda.gov/products/w2q/h\&h/ tools_models/agnps/model.html.

Daverede, I.C., A.N. Kravchenko, R.G. Hoeft, E.D. Nafziger, D.G. Bullock, J.J. Warren, and L.C. Gonzini. 2003. Phosphorus runoff: Effect of tillage and soil phosphorus levels. Journal of Environmental Quality 32(4):1436-1444.

Dillaha, T.A., R.B. Reneau, S. Mostaghimi, and D. Lee. 1989. Vegetative filter strips for agricultural nonpoint source pollution control. Transactions of the ASAE 32(2):513-519

Freeze, R.A., and J.A. Cherry. 1979. Groundwater.Englewood Cliffs, NJ: Prentice Hall.

Hawkins, R.H. 1978. Runoff curve number relationships with varying site moisture. Journal of Irrigation and Drainage Engineering ASCE 104(3):389-398

Hawkins, R.H. 1979. Runoff curve number from partial area watersheds. Journal of Irrigation and Drainage Engineering ASCE 105(3):375-389.

Hjelmfelt, A.T., L.A. Kramer, and R.E. Burwell. 1981. Curve numbers as random variables. In Rainfall-Runoff Relationship, ed. V. P. Singh, 365-370. Water Resource Publications.

Hussein, J., H. Ghadiri, B. Yu, and C. Rose. 2007. Sediment retention by a stiff grass hedge under subcritical flow conditions. Soil Science Society of America Journal 71(5):1516-1523.

Jenson, M.E., R.D. Burman, and R.G. Allen. 1990 Evapotranspiration and Irrigation Water Requirements. American Society of Civil Engineers Manuals and Reports on Engineering Practice No. 70. ASCE.

Johnson, G.L., C. Daly, G.H. Taylor, and C.L. Hanson. 2000. Spatial variability and interpolation of stochastic weather simulation model parameters. Journal of Applied Meteorology 39(1):778-796.

Knight, S.S., and T.D. Welch. 2004. Evaluation of watershed management practices on oxbow lake ecology and water quality. American Chemical Society Symposium Series 877. In Water Quality Assessment in the Mississippi Delta, ed. T.M. Nett, A.M. Locke, and A. Dean Pennington, 119-133. New York: Oxford University Press.

Laflen, J.M., H.P. Johnson, and R.O. Hartwig. 1978. Erosion modeling on impoundment terraces. Transactions of the ASAE 21:1131-1135

Licciardello, F., D.A. Zema, S.M. Zimbone, and R.L. Bingner. 2007. Runoff and soil erosion evaluation by the AnnAGNPS model in a small Mediterranean watershed. Transactions of the ASABE 50(5):1585-1593.

Lindley, M.R., B.J. Barfield, J.C. Ascough II, B.N. Wilson, and E.W. Stevens. 1998. Hydraulic simulation techniques incorporated in the surface impoundment element of WEPP. Applied Engineering in Agriculture 14(3):249-256

Line, D.E. 1991. Sediment trapping effectiveness of grass strips. In Proceedings of the Fifth Federal Interagency 
Sediment Conference. Las Vegas, NV, March 18 21. Volume 2:53-56.

Locke, M.A. 2004. Mississippi Delta Management Systems Evaluation Area: Overview of water quality issues on a watershed scale. American Chemical Society Symposium Series 877. In Water Quality Assessment in the Mississippi Delta, ed. T.M. Nett, A.M. Locke, and A Dean Pennington, 1-15. New York: Oxford University Press.

Locke, M.A., R.M. Zablotowicz, and M.A. Weaver. 2005 Herbicide fate under conservation tillage, cover crop, and edge-of-field management practices. In Handbook of Sustainable Weed Management, ed. H.P. Singh, D.R Batish, and R.K. Kohli, 373-392. New York: Haworth Press.

Locke, M.A., S.S. Knight, S. Smith Jr., R.F. Cullum, R.M. Zablotowicz, Y. Yuan, and R.L. Bingner. 2008. Environmental quality research in the Beasley Lake watershed, 1995 to 2007: Succession from conventional to conservation practices. Journal of Soil and Water Conservation 63(6): 430-442.

Mausbach, M.J., and A.R. Dedrick. 2004. The length we go: Measuring environmental benefits of conservation practices. Journal of Soil and Water Conservation 59(5):97A-103A.

Moriasi, D.N., J.G. Arnold, M.W. Liew, R.L. Bingner, R.D. Harmel, and T.Veith. 2007. Model evaluation guidelines for systematic quantification of accuracy in watershed simulations. Transactions of the ASABE 50(6):885-900.

Nash, J.E., and J.V. Sutcliffe. 1970. River flow forecasting through conceptual models: Part I. A discussion of principles. Journal of Hydrology 10(3):282-290.

Penman, H.L. 1948. Natural evaporation from open water, bare soil, and grass. Proceedings of the Royal Society London Series A 193:120-145.

Rebich, A.R. 2004. Suspended sediment and agrochemicals in runoff from agricultural systems in the Mississippi Delta: 1996-2000. American Chemical Society Symposium Series 877. In Water Quality Assessment in the Mississippi Delta, ed. T.M. Nett, A.M. Locke, and A. Dean Pennington, 104-118. New York: Oxford University Press.

Renard, K.G., G.R. Foster, G.A. Weesies, D.K. McCool, and D.C. Yoder, coordinators. 1997. Predicting Soil Erosion by Water: A Guide to Conservation Planning with the Revised Universal Soil Loss Equation (RUSLE). USDA Agriculture Handbook No. 703.

Robinson, C.A., M. Ghaffarzadah, and R.M. Cruse. 1996. Vegetative filter strip effects on sediment concentration in cropland runoff. Journal of Soil and Water Conservation 50(3):220-223

Shih, G., W. Abtew, and J. Obeysekera. 1994. Accuracy of nutrient runoff load calculations using time-composite sampling. Transaction of the ASAE 37(2):419-429.

Shrestha, S., S.B. Mukand, A.D. Gupta, and F. Kazama. 2006 Evaluation of annualized agricultural nonpoint source model for a watershed in the Siwalik Hills of Nepal. Environmental Modeling and Software 21(7):961-975.

Smedema L.K., and D.W. Rycroft. 1983. Land Drainage. Ithaca, NY: Cornell University Press.

Smith, R.E. 1978. A proposed infiltration model for use in simulation of field-scale watershed hydrology. Presented at Nonpoint Pollution Modeling Workshop. Washington, DC: USDA Agriculture Research Service.

Snipes, C.E., L.P. Evans, D.H. Poston, and S.P. Nichols. 2004. Agricultural practices of the Mississippi Delta. American Chemical Society Symposium Series 877. In Water Quality Assessment in the Mississippi Delta, ed. T.M. Nett A.M. Locke, and A. Dean Pennington, 43-60. New York: Oxford University Press.
Stone, K.C., P.G. Hunt, J.M. Novak, M.H. Johnson, and D.W Watts. 2000. Flow-proportional, time-composited, and grab sample estimation of nitrogen export from an eastern coastal plain watershed. Transactions of the ASAE 43(2):281-290

Suttles, J.B., G. Vellidis, D. Bosch, R. Lowrance, J.M Sheridan, and E.L. Usery. 2003. Watershed-scale simulation of sediment and nutrient loads in Georgia Coastal Plain streams using the Annualized AGNPS model. Transactions of the ASAE 46(5):1325-1335.

Theurer, F.D., and C.D. Clarke. 1991. Wash load component for sediment yield modeling. In Proceedings of the Fifth Federal Interagency Sedimentation Conference, March 18-21, 1991, 7-1 to 7-8.

USDA ARS (Agricultural Research Service). 2007. Generating Climate Data for AnnAGNPS. Oxford, MS National Sedimentation Laboratory, USDA Agricultural Research Service. http://www.ars.usda.gov/Research/ docs.htm?docid $=5199$.

USDA Natural Resources Conservation Service. 1986 Technical Release 55: Urban Hydrology for Small Watersheds. Washington DC: USDA.

USDA Natural Resources Conservation Service. 2007. NRCS Conservation Programs. http://www.nrcs.usda. gov/programs/index_alph.html.

USDA Soil Conservation Service.1985. National Engineering Handbook. Section 4: Hydrology. Washington DC USDA.

Willmott, C.J. 1984. On the evaluation of model performance in physical geography. In Spatial Statistics and Models, ed. G.L. Gaile and C.J. Willmott, 443-460. Norwell, MA: D. Reidel.

Young, R.A., C.A. Onstad, D.D. Bosch, and W.P. Anderson. 1989. AGNPS: A nonpoint-source pollution model for evaluating agricultural watersheds. Journal of Soil and Water Conservation 44(2):168-173.

Yuan, Y., R.L. Bingner, and R.A. Rebich. 2001. Evaluation of AnnAGNPS on Mississippi Delta MSEA Watersheds. Transactions of the ASAE 45(5):1183-1190.

Yuan, Y., R.L. Bingner, and F.D. Theurer. 2006. Subsurface flow component for AnnAGNPS. Applied Engineering in Agriculture 22(2):231-241. 